\title{
НАЦІОНАЛЬНО-КОНЦЕПТНИЙ ПРОСТІР У РОМАНІ ПАНАСА МИРНОГО ХІБА РЕВУТЬ ВОЛИ, ЯК ЯСЛА ПОВНІ?: ПАРАЛЕЛЬНЕ ПРОЧИТАННЯ (тоПос “Дім")
}

\author{
ЖАННА ЯНКОВСЬКА \\ Національний університет “Острозька академія”, Острог - Україна \\ zanna.malva@gmail.com; ORCID: 0000-0002-7846-2796 \\ PRZESTRZEŃ NARODOWO-KONCEPCYJNA W POWIEŚCI \\ PANASA MYRNEGO ХІБА РЕВУТЬ ВОЛИ, ЯК ЯСЛА ПОВНІ?: \\ ODCZYTANIE PARALELNE (topos "Dom") \\ ŻANNA JANKOWSKA \\ Uniwersytet Narodowy “Akademia Ostrogska”, Ostróg — Ukraina
}

STRESZCZENIE. Metoda interdyscyplinarna ma dzisiaj szerokie zastosowanie w humanistyce ukraińskiej, w tym także dla odczytania dzieł literatury pięknej, co pozwala na głębszą, "nielinearną" refleksję. Niniejszy artykuł przedstawia próbę analizy powieści Panasa Myrnego Хіба ревуть воли, як ясла повні? Analiza została przeprowadzona przez pryzmat filozoficzno-kulturowego konceptu Dom - Pole - Światynia (topos "Dom"). W praktyce badawczej koncept ten został wykorzystany po raz pierwszy przez S. Krymskiego dla przedstawienia realiów kultury narodowej.

Słowa kluczowe: folkloryzm, interdyscyplinarny koncept Dom - Pole - Światynia, topos “Dom”, powieść Panasa Myrnego Хіба ревуть воли, як ясла повні?

\section{NATIONAL CONCEPTUAL SPACE OF PANAS MYRNYI'S NOVEL DOES AN OX BELLOW WHEN IT HAS FODDER?: PARALLEL PERUSAL} (topos "Home")

\section{ZHANNA YANKOVSKA}

National University of Ostroh Academy, Ostroh — Ukraine

ABSTRACT. Contemporary Ukrainian scholarship in the humanities taps into the interdisciplinary research methodology which can likewise be used for literary works interpreting. This allows a different perception and a deeper non-linear understanding of the works. This paper is an attempt to analyze Panas Myrnyi's novel Does an Ox Bellow when it has Fodder? through the prism of a philosophical and cultural concept Home - Field - Temple (topos "Home"), which was first used in his research by S. Krymskyi to elucidate the reality of a national culture.

Key words: folklorism, interdisciplinary concept House - Field - Temple, topos "House", Panas Myrnyi's novel Does an ox bellow when it has fodder?

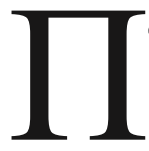

оняття “буття людини” багатовимірне за своїм осмисленням та вивченням, а тому висвітлюється в різних наукових ракурсах і за внутрішньозмістовою осяжністю $є$ фактично невичерпним, оскільки через свою різногалузеву концептуальність характеризується наскрізним полісемантизмом. У зв’ язку із цим виникає потреба аналізу зазначеного поняття з погляду не лише таких наук, як філософія, історія, філологія, етнологія та ін., але й нових, ін- 
тегральних наукових галузей, зокрема етнофілософії, етнокультурології тощо. При цьому необхідно залучати до осмислення як первинний (джерельний), так і вторинний категорійно-теоретичний матеріал. Тому головну ідею, тему твору, характеристику героїв та основні колізії можна розглядати через систему інтердисциплінарних локусів, що дасть змогу цілісно осмислювати культурну епоху, зображену в тексті.

Поняття “інтердисциплінарний локус" розуміємо як ті змістові (сюжетні, образні) колізії твору, що за джерельним матеріалом та його теоретичним осмисленням чітко екстраполюються в ту чи ту наукову гуманітарну галузь (історію, філософію, етнографію тощо) чи в кілька галузей одночасно.

3 урахуванням викладеного буття людини співвідносять з буттям конкретного етносу, нації, що є, відповідно, у складі людської “цілокупності”, характеризується певними етнічними, етнорегіональними культурними особливостями. Екзистенція людини, не просто як особи, а як особистості, оприявнюється через певні форми усвідомленого буття, що здатні рефлектувати в модуси людської присутності у світі. Іншими словами, будь-який простір, який заповнює своєю присутністю людина, стає “людиновимірним", він стає топосом плинності їі буття. У процесі аналізу особливостей протікання такого “людинобуття" вчені окреслили низку універсальних концептів, які пронизують усі його сфери й визначають векторність конкретних моно- чи полігалузевих досліджень.

Однією з таких наскрізних універсалій є й концепт Дім - Поле - Храм, що його відомий український філософ і культуролог С. Кримський, спираючись на праці М. Гайдеггера, зокрема теорію архетипних структур, услід за Г. Гачевим, вивів у площину характеристик для аналізу української культури. Знаковими в цьому напрямі є праці С. Кримського Архетипи української ментальносmi та Архетипи украӥнської культури ${ }^{l}$. Зазначені складники концепту можна використати як своєрідну рухому схему для аналізу зовнішніх (місце проживання, одяг, речі та організація побуту і т. п.) та внутрішніх (характер, ментальність, духовність) виявів культури, що не заперечує взаємопроникнення (як культура матеріальна і духовна), дає змогу враховувати при цьому хронологічні виміри i трансформації. Тут убачаємо своєрідне віддзеркалення національних архетипів в образах, адже буття людини - це перетворення видів людської присутності у світі в певні екзистенціали іiі існування. Інтерпретуючи екзистенціали як назви топосів, що належать до особливого, відмінного від матеріальних предметів та ідеальних сутностей онтологічного пласту довкілля (спираючись на праці С. Кримського), зазначимо, що екзистенціал існування кожної нації розкривається через певні “хронотопи, сигнатури та архетипи” (В. Личковах). Вони стають фундаментом для формування та виявлення міфологічних мотивів, світогляду, художньої культури, релігійної свідомості народу.

Спираючись на позицію М. Бахтіна, Д. Наливайко зазначив, що „література за своєю природою є мистецтвом часопросторовим, «хронотопічним», воно [...] вводить час у простір і простір у час, поєднує їх у феноменологічну цілість. У літературному творі «час згущується, ущільнюється, стає художньо видимим, простір же інтенсифікується, втягується в рух часу, історії. Прикмети часу розкриваються в просторі, і простір осмислюється і вимірюється часом»"

${ }^{1}$ С. Б. Кримський, Архетипи української культури, [в:] Під сигнатурою Софії, Київ 2008, с. 301-319; С.Б.Кримський, Архетипи української ментальності, [в:] Проблеми теорї ментальності, Київ 2006, с. 273-301.

2 Д. Наливайко, Літературна компаративістика вчора і сьогодні, [в:] Сучасна літературна компаративістика: стратегї і методи: антологія, Київ 2009, с. 28. 
Аналіз художніх текстів крізь призму згаданого концепту Дім - Поле Храм лежить у смисловому полі фольклоризму літератури - у широкому розумінні цього терміна, коли до фольклору відносимо не лише усну словесність, але й світоглядні принципи, психологічні особливості, характер та філософськобуттєві орієнтири народу. Із цієї точки зору було проаналізовано окремі тексти періоду романтизму: оповідання Ганни Барвінок, історичний роман П. Куліша Чорна рада й соціально-побутові поеми Т. Шевченка Катерина і Наймичка в монографії Фольклоризм української романтичної прозиз. Таке прочитання текстів не лише не нівелює традиційного літературознавчого аналізу, але суттєво доповнює його, додаючи “стереоскопічності" в розумінні епохи.

Нашу увагу також привертає й проза Панаса Мирного (Панаса Яковича Рудченка), зокрема його соціально-психологічний роман Хіба ревуть воли, як ясла повні?, що має алегорично-паремійну назву. Особливо цікаво спостерігати трансформації і зміщення, що відбулися в змістовому наповненні окремих складників зазначеного концепту з переорієнтацією літератури з романтизму на реалізм.

Внутрішнім поштовхом для створення роману Хіба ревуть воли, як ясла повні? став нарис письменника Подоріжжя од Полтави до Гадячого, а точніше сама подорож навесні 1872 року, під час якої хлопець-візник розповів йому історію про засудженого на каторгу селянина Василя Гнидку, який з доброчесного селянина перетворився на розбійника. Проїжджаючи селами, письменник спостерігав картини життя пореформеного села, і в ці враження вписувалося почуте, витворюючи в уяві письменника вмотивовану цілісність. Нарис вийшов із запізненням (1874 р.), хоч був написаний відразу. На основі нарису Панас Мирний написав повість Чіпка, що не вичерпувала потенційних можливостей сюжету й після конструктивного рецензування твору старшим братом (письменником і літературним критиком Іваном Яковичем Рудченком - Іваном Біликом), автор ще двічі переробляв повість, тому й з'явилися багатоплановість оповіді, інші герої. Текст набув логічно-смислового завершення. Над остаточною (четвертою) редакцією твору брати працювали разом, більше навіть редагував текст Іван Білик. Завершено текст восени 1875 року, твір уже мав назву Хіба ревуть воли, як ясла повні?. Роман було подано до Київського відділу цензури, друк мав розпочатися 1876 року. Проте 5 червня того ж року вийшов сумнозвісний Емський указ про заборону друкування українських книг. Тому автори переслали твір за кордон, і вийшов він 1880 року в Женеві за сприяння М. Драгоманова під назвою Хіба ревуть воли, як ясла повні? Роман з народного життя П. Мирного та І. Біли$\kappa a$. В Україні його вперше було видано у Львові 1887 року та потім двічі в Києві 1903 і 1905 роках, але київські видання вже мали назву Пропаща сила ${ }^{4}$.

Композиція роману досить складна. Із цього приводу О. Білецький навіть писав, що архітектоніка твору нагадує „будинок з багатьма прибудовами і надбудовами, зроблений не одночасно і не за строгим планом" . Проте при його прочитанні відчувається внутрішній, логічний, об'єднувальний стержень, який можна відчути і вмотивувати зображені події, проаналізувавши твір крізь призму універсального філософсько-культурологічного концепту Дім - Поле Храм. На тлі складників топосів цього концепту автори підсвідомо зображують майже півторасотлітню типову історію села Піски з його мешканцями та життє-

\footnotetext{
${ }^{3}$ Ж. Янковська, Фольклоризм української романтичної прози, Львів 2016.

${ }^{4}$ Iсторія украӥнської літератури другої половини XIX ст., за ред. В. М. Поважної та М. С. Грицая, Київ 1986, с. 184-185.

${ }^{5}$ Там само.
} 
вими колізіями. Рельєфно та різнопланово виписано в романі Панаса Мирного Хіба ревуть воли, як ясла повні? національно-буттєвий топос “Дім”, життєвий космос людини, у якому відбуваються всі найважливіші події ііі життя. Цей простір $\epsilon$ не лише матеріально облаштованим прихистком, але він “живе”, віддзеркалює емоційний стан своїх мешканців. Для персонажів-представників різних соціальних станів - це інший життєвий простір, що має неоднакове зовнішнє облаштування та внутрішньосмислове наповнення. Намагаючись якнайглибше осягнути топос “Дім", можна визначити його також як "вмістилище духовного буття людини" (С. Кримський), де виявляється ії ставлення до світу, що грунтується на “інтуїтивізмі” та “кордоцентризмі”. Саме таке ставлення до цього простору подає Панас Мирний (Даруйте за поширений джерельно-цитатний матеріал, адже тільки за його допомогою можна передати сутність заявленої теми, що стосується безпосередньо текстової канви твору).

Художній топос “Дім” в аналізованому творі постає полісемантичним категоріальним формовиявом зі складними взаємовідношеннями: 1) локальне середовище буття (це ті оселі, у яких проходить життя основних героїв), 2) територія, де відбуваються основні події (село Піски) та 3) загалом рідний край, що протиставляється чужому (“Донщина” та “Московщина”). Можна розмірковувати про метафорично-символічну семантику цього простору як індивідуальну організацію характеру й душевного стану героїв - це простір екзистенційний, внутрішній, який М. Бахтін назвав “душевним ландшафтом”. Саме тому йдеться про зображення осель, їхній стан як такий, що в різних планах гармонійний з їхніми господарями, що будемо спостерігати під час аналізу.

Передусім звернемо увагу на те, як виникло село і які оселі були в Пісках „за півтори сотні літ” „перед волею”: Тоді „Пісок і сліду не було. Там стояло невеличке сільще, або краще - невеличкі хутіриі розсипались по балиі, як стоги сіна зимою по степу. Мазанок було, може, хат з п'ять, а то все - землянки при самій землі, як могилки, повіддималися. Тільки один димар нагадував, що то не барлога звіряча, а людська оселя, що берегла людей од звіра і од лихої години. Землянка була з присінок, схожих на рів, та хати-льоху. У хаті була піч, де можна зварити їсти та погрітися; одним одно віконечко - мале, як оддушина у бджоляниках, виглядало збоку на шлях". Такий життєвий простір віддзеркалював відповідний уклад життя і свідчив про те, що там знаходили пристанище бідні втікачі-переселенці. Із часом село розрослося, розбагатіло, було вільним (хоч неволя вже нависала над ним), тому й змінювався життєвий простір його поселян. Коли Мирін Гудзь, який “світа побачив” у чужій стороні, закликав повстати проти існуючих порядків, бо розумів, що насувається неволя, односельці, задоволені тимчасовим спокоєм, не були готові до рішучих дій і в роздумах розходилися по домівках, утішаючись примарними надіями, не в змозі передбачити біду, що на них насувається. Вони надавали перевагу споконвічній хліборобській праці, порівн.: „I порплиться кожен собі в господі, як курка на гнізді. Вимощує, підмошує, смиче, обсмикує, курчат висиджує... Ростуть Піски - $і$ багатіють... Не вряди-годи - дивись: ні відсіль, ні відтіль та вирветься який захожий: або з нової Січі, з-під турка (бо та віра турещька, земля бусурманська!), або з-за Дніпра, від ляхів - та все на вільні степи, все на вільні степи... Зопне курінь, викопає землянку, візьме жінку та й зажи-

${ }^{6}$ М. М. Бахтин, Проблемы сентиментализма, [в:] Собр. соч., в 7 томах. , т. 5: Работы 1940-х - нач. 1960-х г2., Москва 1997, с. 364.

7 Панас Мирний, Хіба ревуть воли, як ясла повні?, [в:] Твори, у 2 томах, т. 1, Київ 1985, c. 296. 
ве тихим хліборобом. Глянь: землянка по землянці, мазанка по мазанці - з невеличких хутіриів набралося хаток на џіле село, з улииями, з городами, з садками, з левадами!"”. Але лихо прийшло у вигляді кріпацтва. I коли цариця дарувала Піски пану Польському, Мирін поїхав та привіз “бумагу”, що він записаний ,, в компут”, а тому „,довіку вільний, і сім'я його, нащадки його навіки вільні; а хто не записаний, - тому генераловим бути..."”. А свій вільнолюбивий та нестримний характер Мирін передав своєму внуку Максиму, який „полюбив діда більше батька, матері".

Найбільш повно топос “Дім" в аналізованому романі відображений як той, де проживає головний герой Чіпка Вареник. Оскільки він має дуже мінливий характер (іноді він лагідний, навіть ніжний, працьовитий, коли ж, шукаючи правди, бачить одну неправду, стає непокірним, нестримним, навіть позвірячому злим), то так само різним постає і його дім. У зв'язку з обставинами життя змінюється й ставлення до цього життя; як наслідок - змінюється і життєвий простір. Дім, де зростав Чіпка, купив його батько Іван Вареник (його він навіть не пам'ятав) ще до одруження з Мотрею - матір'ю хлопця. Це наповнило життя жінки змістом, уселило надію на краще майбутнє, тому під ії працьовитими руками оживає стара оселя, ніби радіючи разом 3 нею, із чужої стає своєю, порівн.: ,Як уступила Мотря в свою хату, то немов знову на світ народилася. Чепурить їі прибира. Діждали весни, - огород одкопала, скопала, засадила; хату вимазала, оббілила; приспу жовтою глиною підвела; коло хати віником обмела. Чисто кругом - любо глянути, і огородина зеленіє..." ${ }^{10}$. Як наслідок ця оселя швидко набуває зовсім іншого вигляду і демонструє певний лад (хоч і тимчасовий), який панує в ній, порівн.: „На самому краї села, од вигону, стояла невеличка хатка, вікнами на широкий шлях. 3-за хатки виглядали невеличкі хлівиі, повіточки; трохи далі-тік; за током - огород; а все кругом обнесено низенькою ліскою... Зразу видно було, що то плеиь не дуже заможного хазяїна. Не достатки, а тяжка прачя кидалась в вічі. Хата хоч старенька, та чепурна, біла - видно, біля неї ходили хазяйські руки; двір виметений, чистий; огорожа циіла, хоч і низенька, а ворота дощані, хрещаті"'ll. Та горе не забарилося вступити в їхне тимчасове щастя. Коли батько Чіпки пішов нібито на заробітки, аби розжитися, приходить звістка про те, що він “двужон” - на “Донщині” залишив дружину з трьома дітьми та із чужим “пашпортом” повернувся в рідне село, яке залишив ще підлітком. Коли Мотря дізналася, хто насправді ії чоловік, вона ,не переставала плакати. Гіркий ї̈ плач, стогнання матері зливалися вкупу, носилися по хаті, слались по білих стінах"'12. Коли в селі почули, хто ж насправді Мотрин чоловік, відцуралися від неї, обмовляли; горе ніби чорним рядном накинуло жінку, змінилося ії життя - i хата змінилася, порівн.: „Казали, що до Мотрі кожної ночі змій у димар літає: якийсь захожий чоловік застав його у хаті та насилу з душею вирвався... Непевне місие! Бувало, уночі ніхто не пройде повз їх хату, не перехрестившись; а дітям - то й удень забороняли туди бігати... Місиина справді стала пустирем одгонити. Лежить за селом, на самому белебні, неогороджена, не обкопана - так рівець невеличкий прокопаний, та й годі... Iде скотина - нема перепону - через грядки так i чеше; собаки так і гніздяться, кубла повибивали... Пустир пустирем! Хата

\footnotetext{
${ }^{8}$ Там само, с. 392.

${ }^{9}$ Там само, с. 308.

${ }^{10}$ Там само, с. 247.

${ }^{11}$ Там само, с. 243.

${ }^{12}$ Там само, с. 250.
} 
хоч стара була, та як полагодив був Остап, поки ще не женився, то вона, мов, i бадьорилася; а як піднялася лиха година, що замчала не тільки лад в хаті, а й самого Остапа, - то й хата осунулася... Стріха місиями попрогнивала, покрівля де-где провалилася, вікна побиті: замість шибок - ганчірки світять; ще до того дощ та хуртовина оббила, общмарувала... Пусткою аж воняє! I всередині не краще..."”. Х. Хата ніби живе життям своїх мешканців, радіє, гарнішає разом з ними і страждає. Тут виразно проступає фольклорний складник тексту, оскільки в згаданому епізоді спостерігаємо, як скалки міфів оживали в казкових героях і навіть проникали в реальне життя.

Народження Чіпки принесло Мотрі та їі старій матері, яку дуже любив малий, і труднощі (побільшили спочатку їхні злидні), і надію на те, що коли він виросте, то буде кому працювати та доглянути їх у старості. Час залікував душевні Мотрині рани, а син, досягши підліткового віку та не проявивши бажання працювати на багача в стайнях біля худоби (мало не спалив хліва), став підпасичем біля овечок разом з таким же хлопцем-сиротою Грицьком у діда Уласа. Роздолля степу ніби заспокоювало Чіпку, спонукало до роздумів, у нього виникають недитячі серйозні запитання, на які відповідає старий пастух. В образі дворового кріпака діда Уласа проглядається архетип Мудрого Старого, проте це тема іншого дослідження. Він став духовним наставником Чіпки, замінив йому батька, тому пізніше хлопець сумує за ним. Від діда вперше він дізнається й правду про свого батька, стає сумним, задумливим, цими думками ділиться 3 матір'ю. Він тепер починає розуміти, чому з ним не хочуть гратися інші діти та називають байстрюком. Оселя також “реагує” на його сум, порівн.: „Сумно стало в хаті, як у льоху... "'14. Проте все, що дізнався Чіпка про батька, не викликає ненависті. Скоріше, навпаки, син починає перейматися долею батька, намагається уявити його добрим і турботливим, розуміючи, що, скоріш усього, ніколи його не побачить: „Не знав ти долі від самого малку - може, аж до смерті... Ганяла вона тебе з одного краю світа на другий: од панського двору до Дону, од Дону - до прийому...Де ж тепер ти? [...] А може, тебе доля занесла куди у далеку чужину, на інший край світу, ти думаєш-гадаєш, не досипляючи ночей, про матір..." 15 . Заробіток підпасича був невеликий, проте й він відчутно покращив становище сім'ї, де раніше не покладаючи рук працювала одна лише Мотря. Чіпка став заробляти “шага”, „мішків з п’ять” хліба та „ягнят двоє або троє на рік”: , Отак радіють та Богові не надякуються, що хоч трохи втекли од тих важких злиднів, нужди, горя... I в хаті у них стало чепурніше, ясніше; [...]. I зокола хата обмазана, хоч рудою глиною, та все ж рівненько; зверху полатана - не світить гнилою, дірявою оселею..." ${ }^{\prime 6}$. Як бачимо, знову повеселів Дім, з'явилася надія на краще життя. Ще відрадніше стало родині, коли Мотря, отримала в спадок шматок землі. Ставши дорослішим, Чіпка відчув себе "хазяїном". Земля зайняла всі його думки. Та землю відібрали, а щоб повернути, суддя Чижик заправив надто велику суму. Ледь зібравши самостійно перший урожай, він не встиг пустити його на користь сім'ї. І оселя ніби відчувала це горе, також занепала, порівн.: „На хаті стеля попрогнивала - крізь стелю капле, стіни осінні дощі общмарували - голими ребрами хата світить..."17. Із цього часу починається моральне та духовне падіння Чіпки. Не знайшовши

\footnotetext{
${ }^{13}$ Там само, с. 254-255.

14 Там само, с. 277.

15 Там само.

${ }^{16}$ Там само, с. 271.

${ }^{17}$ Там само, с. 365 .
} 
правди, він стає на “слизьку дорогу”, топить горе в горілці й зв’язується з таким самим пропащим товариством - Лушнею, Пацюком і Матнею. Він занехаяв себе, матір та свій Дім-оселю і Дім душі. Наслідком такої поведінки стала реакція матері, яка за порадою людей заявила на сина у волость, за що він, послухавши своїх товаришів, затаїв на неї злість, а оселя знову стала пусткою: „, Стояла уже пізня осіння пора. Холодний вітер вривався в побиті шибки й навпростець віяв у розчинені двері, щуо покинув за собою Чіпка. Мотрі зробилось холодно. Устала вона з печі, щзоб хоч двері зачинити. Гляне - у хаті, як у пустці: стіл перекинутий, горики побиті, скриня розчинена... Кинулась Мотря до скрині - та й охолола... Там усе перевернено, порито - $і$ свити немає..." 18 . Згорьована мати, „зв'язавши останнє своє збіжжячко у клуночок, перекинула через плече, перехрестилася - i пішла до сусіди, старої баби пупорізки, шо жила недалеко від їх дворища"” 19 . Баба та дівчина, у яких знайшла притулок Мотря, ніби й не ображають іiі, вона вносить посильну частку в спільне життя, але це для неї чужий простір. Думки про свій Дім не покидають жінку, вона сумує за сином, хоч у розпачі й проклинала його, сумує за своєю хатою, де була повноправною господинею, порівн.: „Тяжко їй робилося на душі, гірко на сериі, як подумає, щзо на старості літ прийшлося наймичкувати у людей. I хата своя, й достатки, хоч які там не які були, а все б таки жити можна... А прийшлося в чужій хаті людям годити, людей слухати... ”20. А син їі тим часом гуляє: „,Немає тоді Чіпиі впину, немає заборони, бо й у хаті нікого немає... Так, з побитими вікнами, стояла вона на край села пусткою" "21, передаючи спустошеність душі Мотрі та й самого Чіпки. Хата стала схожа на “барлогу”. Іноді, протверезівши, він думками повертається в минуле, коли його сакральний життєвий простір виглядав зовсім інакше. Тоді задумується: „А тепер? Серед пустки неметеної, у смітті, у багнюиі, валяється - обірваний обшарпаний, як волочюга, як харцииза який... А до и̧ього щзо витворяв?! Де ділася кобила, вівиі, корова? Де одежа, щуо мати справила? Де ділася мати, куди вона пішла? де приклонила сиву голову?! Сиротою стоїь над иляхом хата, з побитими вікнами, нетоплена, необшпарована, чорна...”22. Багато уваги приділяє Панас Мирний зображенню цього життєвого простору. Для нього Дім і його мешканці - єдине ціле. Зрештою, так було й залишається завжди. Тільки не всі задумуються про те, адже кожен, облаштовуючи свою оселю, створює власний світ, у якому йому комфортно. У час боротьби з неправдою та із собою оселя Мотрі та Чіпки справляла гнітюче враження. Здавалося, що і природа це відчуває, порівн.: „, Осіннє сонще сідало у хмари. Прощаючись з землею, заливало хмари й землю огняним світом. Як кров, червонів захід сония $i$ заглядав своїми червоними очима крізь побиті шибки у Чіпчину хату..." 23 . Але і в такому занепалому стані були цінності, яких головний герой не може продати жидові навіть за добру ціну, хоч і товариші намовляють, - це власними руками вирощений хліб. Він віддає його задарма своєму товаришеві дитинства Грицькові, який на той час уже став статечним господарем. Коли Грицько приїхав за хлібом до Чіпки, побачив гнітючу картину: „Пуста городина, лихий тин, криві ворота, не обмазана хата з побитими вікнами неприязно кинулись в вічі й образили Грищькову хазяйливу нату-

\footnotetext{
${ }^{18}$ Там само, с. 389.

19 Там само, с. 390.

${ }^{20}$ Там само, с. 407.

${ }^{21}$ Там само, с. 390.

22 Там само, с. 409.

${ }^{23}$ Там само, с. 409-410.
} 
ру... Він з докором і разом з жалем дивився на Чіпчине добро..."24. I все-таки це був переломний момент у житті Чіпки. Побувавши в затишній теплій хаті Грицька, надивившись на його тихе сімейне життя із Христею в злагоді та розумінні, побачивши статки товариша, він ніби ожив, його серце відігрілося, згадав про свою “польову царівну” Галю та знайшов сили відмовитися й від нових товаришів, і від розбою, і від розгульного життя. Це переломний епізод твору, де йдеться про те, як ,, посеред хати, освіченої місячним світом, щзо через вікна вривався в хату, слався широкими смугами по долівці і ховався аж під полом, стояв Чіпка навколішки і молився... прокльонами. Сльози блищали у його очах; він клав щүиро поклони..."25. Це була дивна й страшна молитва, коли замість звернення до Бога , уста шептали гіркі прокльони, перечитуючи свої гріхи... "26. Покаяння ніби очистило його душу. Парубок іде до матері, перепрошує іiі, Мотря, як і кожна мати, ураз забуває свої кривди та з нетерпінням чекає весни аби повернутися до своєї, хай ще занехаяної, але такої рідної оселі. Дочекавшись тепла, ,вкупі з матір'ю він день у день коло хати порається. Розкрив ї̈, оббив зокола й зсередини; трухляве дерево викидає, нове вставляє - иіле; нові крокви становить, околотом вшиває... [...]. До Паски вже стояла хата, як та чепурна дівчина: рівна, висока та біла-біла, як сніг. I можна було бачити, як кожного ранку й вечора виходила з неї старенька жінка, трохи згорблена, з веселим поглядом у очах. Хутко вона бігла до ожереду соломи, щзо стояв на вгороді, хутко набирала повне рядно й несла через силу у хату. То була Мотря. Аж помолодшала вона, як перебралася в свою хату, на нове хазяйство... [...] Полагодив хату, - давай погріб обчищати та оброблювати, трунт новою лісою обплітати, дощані ворота майструвати. Об Миколаї на ярмарку овечат купив...”27. Збулася й інша мрія Чіпки та Мотрі - він одружився на Галі, яку з першого погляду вподобав, зустрівши ще біля свого поля. Прихід молодої та заможної дружини (Максим Гудзь дав гарне придане за донькою) також змінив їхню оселю та й загалом життя, наповнивши його радістю, злагодою, бо невістка знайшла спільну мову зі свекрухою, порівн.: „,Гарно, весело тепер у їх хаті. Сама хата - наче побільша, роздалася, повеселішала. Стіни Галя убрала шпалерами, пообвішувала рушниками. 3 божничка виглядали дорогі образи з-за лісу васильків, м'яти, ласкавичі, гвоздиків та мов усміхалися, дивлячись на хату. Перед образами гойдалися на ниточках роблені голуби"28. Радість, що оселилася в їхньому Домі, зробила його затісним, тому, маючи достаток, вони будують нову оселю: „Тільки діждав Чіпка тепла, зараз накупив дерева, найняв майстрів $i$ заложив над самим шляхом не хату, а иілий невеличкий будинок. Поки люди налагодились з жнивами, то на його дворі, замість похилої хатини, стояв веселий будинок i гордо позирав на вулицю великими вікнами з зеленими віконницями. Давня Чіпчина гадка справдилась. Тепер уже не одна тісна хата з сіньми, а ичілих три: одна - для матері, друга - для себе, а через сіни світлиия - про гостей. Недалеко од будинку складали рублену комору. Трохи далі, як поставили комору, заходились коло сараю з конюшнею: а там - $i$ загороду заплели нову, кругом дворище обгородили новою лозовою лісою з острішком... Старі ворота поламав Чіпка, а прибив дощані, панські, розтворчаті..."29. "Розтворчаті” ворота

\footnotetext{
${ }^{24}$ Там само, с. 403.

${ }^{25}$ Там само, с. 439.

${ }^{26}$ Там само.

27 Там само, с. 453-454.

${ }^{28}$ Там само, c. 491.

${ }^{29}$ Там само, с. 500.
} 
тут символізують відкритий шлях у нове життя і разом з “лозовою лісою” власний відмежований простір, де, як писав Тарас Шевченко, „своя правда, i сила, і воля". Проте недовго тривала ця сімейна ідилія. I на заваді стало навіть не те, що Галя не народила для Чіпки дитини, хоч це й засмучувало. Дівчина мріяла вирватися з рідного дому, хутору, бо ії гнітив розбійницький та грабіжницький спосіб життя ії батьків. Вона не боялася бідності, а хотіла жити, чесно заробляючи на хліб. Галя по-своєму любила батьків, як і вони іiі, одиначку, пестили та не відмовляли ні в чому. Лихо було в тому, що Максим Гудзь та його товариші знову затягують Чіпку в розбійницьке та грабіжницьке життя, де була легка пожива. Максима Гудзя було побито, і він за кілька днів помер. Явдоха переїхала до Чіпки, почалися в них чвари та нелад, матері не поладили, то й діти між ними не могли жити в мирі. Мотрю знову зневажали. Та ще коли Чіпку за гласного обрали й неправдою виключили зі списку, то знову запеклася ця неправда в Чіпчиному серці, порівн.: „Такі безперестанні бучі та гризня доливали отрутою й без того вже отруєне життя Чіпчине. У своїй хаті він був, як чужий: вона йому остогидла. Йоу було у ній душно, тісно; серие забажало волі, душа - простору..."зо.

Зважаючи на всі згадані обставини та стосунки в родині, змінюється і життєвий простір хати, порівн.: „Настали часи інші, завелись порядки другі у Чіпчиній хаті. Привітна й тиха своїм спокійним сімейним побитом, стала вона тепер притоном гульні п'яної, несамовитих реготів, співів..." в хаті горілка тепер господиня. Рідко проходив той день, щоб п'яне гульбище не збиралося, не гуло, не кричало... А коли не гульня, - то гризня жіноча: матері як не кусають одна одну..." "з2.

Одруження Чіпки можна трактувати двояко: Галя принесла в його життя кохання, а в Дім - життєву силу й тепло, але, потрапивши під вплив їі батьків, Чіпка не зміг протистояти легкому збагаченню, знову зійшов на “слизьку дорогу”, занепастивши і своє життя, і життя своїх близьких. Тому залишився він у пам'яті односельців та й усієї округи “страшним чоловіком”, бо в п'яному тумані під час грабежу вирізав цілу сім'ю, порівн.: „Недалеко од Пісок, над самим шллхом, коло Хоменкового хутора, насипана висока могила, на ній стоїть височенний хрест - оглядає навкруги хутори, села, всі околиці... Під ним тліє вісім безневинних дуи, загублених в одну ніч..." "зз.

У кінці роману символічно описано три оселі, що ніби протиставляються: панський палац, Храм-церкву та Чіпчину хату, порівн.: „, А посеред села, напроти похилої иерковиі, тоне в саду, як у раю, видивлясться на свою красу у ставкові води поновлений палаи - у позолоті, у розкошах. В йому тепер живе новий хазяїн Пісок - перший дукач на все Гетьманське Данило Павлович Кряжсов"з4. "Похила церковця" символізує духовний занепад, а палац “у позолоті” - перемогу неправди, проти якої всією душею повставав головний герой. А Чіпчина хата описана так: „,Стояла на край села сиротою пустка - завидувала палаиу. Аж ось - випало й ій несподіване шастя: купив ї̈ у казні за безцінок давній знакомий - жид Гершко, причепурив трохи зокола облупані боки, полатав, де попрогнивала, оселю-та й завів шинок. Щонеділі, щосвята, а часом і серед будня, щоб не одстати од вельможно-

\footnotetext{
${ }^{30}$ Там само, с. 531.

${ }^{31}$ Там само, с. 534.

${ }^{32}$ Там само, с. 538.

${ }^{33}$ Там само, с. 551.

${ }^{34}$ Там само.
} 
го сусіди, - бенкетує тут n'яне море темной простоти... "35. Те, що згубило Чіпку, оселилося в його Домі, аби загубити ще не одну душу й родину.

На рівні персонажів твору топос “Дім” найбільш цілісно представляє Грицько. На заробітках він мріяв про власне обійстя, землю, а придбавши їх, повністю відданий життю в цьому просторі, фактично жодного разу концептуально не виходить за його межі.

С. Кримський визначає Дім як „святу округу буття людини, в якій він посідає центральне місце”, Дім, на думку вченого, „символізує й сім’ю, й забезпеченість особистості, рівень ії заможності та соціальної захищеності. Дім - це антропоцентричне буття, ніша людини в драматичному світі" 36 . О. Кирилюк дещо доповнив це визначення: “Дім” — „певна область трансцендування людини у світ" 37 , оселя, житло, хата, сфера їі фізичного буття, центр, що розширюється від обійстя, власної землі, хутора до населеного пункту, країни (“Дім національного буття"), про що згадує також Є. Більченко ${ }^{38}$.

До цього топосу причетні всі персонажі твору. Головний герой роману - Чіпка - також репрезентує цей топос, проте в його образі переплелося тяжіння до усіх трьох буттєвих просторів зазначеного концепту, про що більш детально можна стверджувати, проаналізувавши складники концептів "Поле" та "Храм", що також відображені в романі. В. Личковах уважає, що „Дім, Поле $i$ Храм - це топоси дійсного буття людини, що визначають горизонти ії вкоріненості, «Край» іiі особистого і родового, етнонаціонального існування"з9.

Отже, життєвий топос “Дім” універсального концепту Дім - Поле - Храм у романі Панаса Мирного Хіба ревуть воли, як ясла повні? висвітлений різноманітно, що особливо яскраво виявляється під час характеристики образів твору, адже життєвий простір “розповідає” не лише про характери, психологію, ментальність окремих персонажів, але й народу загалом.

\section{Список використаної літератури}

Бахтин М. М., Проблемы сентиментализма, [в:] Собр. соч., у 7 томах, т. 5: Работьл 1940-х - нач. 1960-х г2., Москва 1997.

Більченко С. В., Мотив чужого у формуванні етнокультурної ідентичності украйнців, [в:] „Вісник Чернігівського державного пед. університету. Серія «Філософські науки»", Чернігів 2010, вип. 75, с. 84-88.

Історія украӥнської літератури другої половини XIX cm., за ред. В. М. Поважної та М. С. Грицая, Київ1986.

Кирилюк О. С., Універсально-культурні структури міфологічних підвалин масової політичної свідомості, [в:] Універсальні виміри культури, Одеса 2000, с. 27-38.

Кримський С. Б., Архетипи української культури, [в:] Під сигнатурою Софії, Київ 2008, c. 301-319.

Кримський С. Б., Архетипи української ментальності, [в:] Проблеми теорії ментальності, Київ 2006, с. 273-301.

35 Там само.

${ }^{36}$ Там само, с. 427.

${ }^{37}$ О. С. Кирилюк , Універсально-культурні структури міфологічних підвалин масової політичної свідомості, [в:] Універсальні виміри культури, Одеса 2000, с. 29.

${ }^{38}$ С. В. Більченко, Мотив чужого у формуванні етнокультурної ідентичності украӥнців, [в:] „Вісник Чернігівського державного пед. університету. Серія «Філософські науки»”, Чернігів 2010, вип. 75, с. 86 .

39 В. А. Личковах, Філософія етнокультури як новітній напрям, [в:] „Вісник Чернігівського державного пед. університету. Серія «Філософські науки»”, Чернігів 2010, вип. 75, с. 5. 
Личковах В. А., Філософія етнокультури як новітній напрям, [в:] „Вісник Чернігівського державного пед. університету. Серія «Філософські науки»", Чернігів 2010, вип. 75 , с. 3-9.

Мирний Панас, Хіба ревуть воли, як ясла повні?, [в:] Твори, у 2 томах, т. 1, Київ 1985, c. $239-551$.

Наливайко Д., Літературна компаративістика вчора і сьогодні, [в:] Сучасна літературна компаративістика: стратегії і методи: антологія, Київ 2009, с. 5-42.

Янковська Ж., Фольклоризм української романтичної прози, Львів 2016.

\section{Spysok vykorystanoi literatury [References]}

Bahtin M. M., Problemy sentimentalizma [Problems of Sentimentalism], [v:] Sobr. soch., u 7 tomah, t. 5: Raboty 1940 h-nach. 1960 h gg., Moskva 1997.

Bilchenko Ye. V., Motyv chuzhoho u formuvanni etnokulturnoi identychnosti ukraintsiv [Motif of Foreign in Formation of Ethnocultural Identity of the Ukrainians], [v:] „Visnyk Chernihivskoho derzhavnoho ped. universytetu. Seriia «Filosofski nauky»", Chernihiv 2010, vyp. 75, s. 84-88.

Istoriia ukrainskoi literatury druhoi polovyny XIX st. [History of Ukrainian Literature of the Second Part of the XIXth Century], za red. V. M. Povazhnoi ta M. S. Hrytsaia, Kyiv1986.

Kyryliuk O. S., Universalno-kulturni struktury mifolohichnykh pidvalyn masovoi politychnoi svidomosti [Universal Cultural Structure of Mythological Fundamentals of Mass Political Consciousness], [v:] Universalni vymiry kultury, Odesa 2000, s. 27-38.

Krymskyi S. B., Arkhetypy ukrainskoi kultury [Architypes of Ukrainian Culture], [v:] Pid syhnaturoiu Sofii, Kyiv 2008, s. 301-319.

Krymskyi S. B., Arkhetypy ukrainskoi mentalnosti [Architypes of Ukrainian Mentality], [v:] Problemy teorii mentalnosti, Kyiv 2006, s. 273-301.

Lychkovakh V. A., Filosofiia etnokultury yak novitnii napriam [Ethnoculture Philosophy as New Direction], [v:] ,Visnyk Chernihivskoho derzhavnoho ped. universytetu. Seriia «Filosofski nauky»", Chernihiv 2010, vyp. 75, s. 3-9.

Myrnyi Panas, Khiba revut voly, yak yasla povni?, [v:] Tvory, u 2 tomakh, t. 1, Kyiv 1985, s. 239-551.

Nalyvaiko D., Literaturna komparatyvistyka vchora $i$ sohodni [Literature Comparativistics Yesterday and Today], [v:] Suchasna literaturna komparatyvistyka: stratehii i metody: antolohiia, Kyiv 2009, s. 5-42.

Yankovska Zh., Folkloryzm ukrainskoi romantychnoi prozy [Falklore of Ukrainian Romantic Prose], Lviv 2016. 